\title{
陰圧式強制換気温室におけるタバココナジラミに対する 天敵寄生蜂サバクツヤコバチの防除効果
}

\author{
杉山恵太郎・大石直記・西東 力* ・守谷栄樹**
}

Keitaro Sugiyama, Naoki Ooishi, Tsutomu Saito* and Hideki Moriya**: Control of the whitefly

Bemisia tabaci (Hemiptera: Aleyrodidae) by using the parasitoid Eretmocerus eremicus

(Hymenoptera: Aphelinidae) in a tomato greenhouse with a negative-pressure forced ventilation system

\section{Summary}

The whitefly Bemisia tabaci population was controlled in a tomato greenhouse with a negative-pressure forced ventilation (NFV) system by using the parasitoid Eretmocerus eremicus from August to November. The NFV system was used in combination with a fine mesh-sized insect-proof screen, and a wind speed velocity of approximately $1 \mathrm{~m} / \mathrm{s}$ was used. Similar experiments were performed in a greenhouse with natural ventilation (NV). In September, the mean temperature in the NFV greenhouse was $0.9-1.6^{\circ} \mathrm{C}$ lower than that in the NV greenhouse. By early- and mid-November, the number of parasitoids and the rate of parasitism in the NFV greenhouse were comparable to that in the NV greenhouse. By mid- and late-October, the number of $B$. tabaci adults and nymphs in the NFV greenhouse were comparable to that in the NV greenhouse. These findings suggest that the searching behavior and the development of parasitoids were not affected by the ventilation and that E. eremicus can successfully control whiteflies in an NFV greenhouse.

\section{緒言}

施設トマトでは, タバココナジラミBemisia tabaci が 重要害虫で, 吸汁による生育阻害, 排泄する甘露によ る外観污損, トマト黄化葉巻病ウイルス (Tomato yellow leaf curl virus: TYLCV) などのウイルスの媒介などの被 害を引き起こし問題となっている

タバココナジラミに対する化学的防除法は, 殺虫剂抵 抗性の発達により難しくなっているため ${ }^{12)}$, 天敵寄生蜂 を利用した生物的防除法が検討されてきた ${ }^{2)}$ 。国内では, サバクツヤコバチ Eretmocerus eremicus, チチュウカイ ツヤコバチE. mundus, オンシツツヤコバチ Encarsia formosa の 3 種の天敵寄生蜂がコナジラミ類に対する生 物農薬として登録されている。これらの寄生蜂は，施設 の総合的病害虫管理（IPM）の生物的防除資材として利 用されている

また, タバココナジラミの物理的防除法としては, $0.4 \mathrm{~mm}$ 目合い以下の防虫ネットを温室の開口部に展張 することにより，タバココナジラミの野外からの侵入を 抑制し，TYLCVの発生も抑制することが明らかになっ

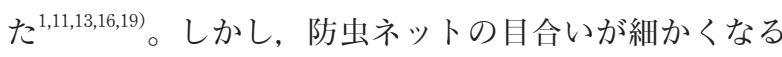
と夏季の温室内の気温が高くなり, 作物の生育, 着花, 果実肥大等に影響し，作業能率の低下などの問題が生じ ることが指摘されている ${ }^{4,8,13,15)}$ 。温室内の気温を下げる ために，遮光資材 ${ }^{4)}$, 循環扇や換気扇が利用されている。

最近, 換気量を従来の 2 倍に高め室内の昇温抑制効果 を向上させた新しい強制換気システム（陰圧式強制換気 システム）が開発され，静岡県内のトマト栽培に導入さ れている ${ }^{17)}$ 。この温室の夏季の気温は, 慣行の自然換気 温室に比べ約 $2^{\circ} \mathrm{C}$ 低く, トマトの蒸散効率が高まること から, 生育, 果実品質が向上する ${ }^{17)}$ 。一方, 温室内には 風速 $2 \mathrm{~m} / \mathrm{s}$ 程度の風が常に流れていることから, 害虫や 天敵の発生, 行動などに影響があると考えられる。特に ツヤコバチのように微小な天敵寄生蜂の利用にあたって は, 風がハチの探索行動を妨げて, 寄生率が低下し, 防 除効果が低下することが懸念される。

そこで，陰圧式強制換気システムに目合いの細かな防 虫ネットを組み合わせた強制換気温室と自然換気温室に おいて, タバココナジラミに対するサバクツヤコバチの

静岡県農林技術研究所・*静岡大学・**中部電力（株） Shizuoka Prefectural Research Institute of Agricultural and Forestry, *Shizuoka University, ${ }^{* *}$ Chubu Electric Power Co., Ltd. 2012年 2 月17日受理 
防除効果を比較し, 新しいシステムの温室における天敵 寄生蜂の利用技術の有効性の評価を行った。

\section{材料および方法}

\section{1. 試験温室}

試験は，2004年の $8 \sim 11$ 月に静岡県農林技術研究所 内の隣接した同規模の 2 棟の温室 $(7.4 \mathrm{~m} \times 14.6 \mathrm{~m} \times$ 高 さ $4 \mathrm{~m})$ 内で行った。一方の温室を強制換気温室 (NFV greenhouse）（Fig. 1，A）とし，陰圧式強制換気システム に目合いの細かな防虫ネットを組み合わせた。温室の北 側に換気扇（フルタ電気（株）社製（TCW8944BF），高 さ $0.7 \mathrm{~m}$, 換気扇の羽根の直径 $0.8 \mathrm{~m}$ ）を 3 台, 南側妻 面に $0.4 \mathrm{~mm}$ 目合いの防虫ネットを張った吸入口を 2 つ （高さ $0.8 \mathrm{~m}, 0.8 \mathrm{~m} \times 0.8 \mathrm{~m} ）$ 設置した。温室内の出入り 口は南側に設置し, 内部に $0.4 \mathrm{~mm}$ 目合いの防虫ネット で覆った部屋を設け，外気が直接内部に入らないように ネットを開閉して出入りした。天密と側密には, $1 \mathrm{~mm}$ 目合いのネットを設置した。換気扇は，午前 6 時〜午後 6 時の間は，室温が $25^{\circ} \mathrm{C}$ 以上の時に稼働するように設 定し，換気扇の稼働時間帯は天空と側空は閉めた。温 室内の気圧を約 $15 \mathrm{~Pa}$ ，㽞間の風速が約 $1 \mathrm{~m} / \mathrm{s}$ になるよ うに調節した。もう一方の温室は自然換気温室（NV greenhouse）（Fig. 1, B）とし，天空，側空に $1 \mathrm{~mm}$ 目合 いの防虫ネットを展張した。2つの温室とも暖房はしな かった。

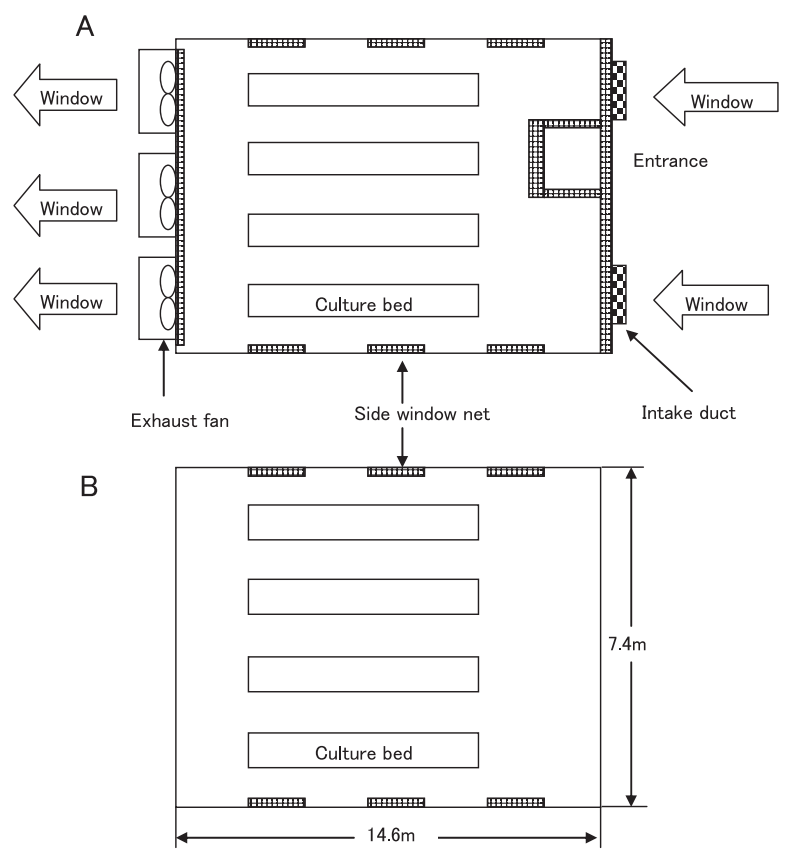

Fig. 1. Illustration of $(A)$ a tomato greenhouse with a negativepressure forced ventilation (NFV) system and (B) a tomato greenhouse with natural ventilation (NV).

\section{2. 供試作物}

2004年 8 月 6 日にトマト (品種 : 桃太郎ヨーク)をロッ クウールの細粒を培地とした 3.5 号ポットに植え点滴灌 水栽培を行った。

\section{3. 供試虫}

タバココナジラミバイオタイプ B は，2001年に研究 所内のトマトから採取し, 実験室内においてキャベツで 累代飼育している個体群の成虫を試験温室に放飼した。 放飼量は2004年 9 月 9 日に各温室に400頭（株あたり 3.1 頭）を 2 本の管瓶に分け温室の南北に静置し放虫した。 放虫は夕方行い, 管瓶を静置後翌日まで換気扇は止めた。 タバココナジラミの天敵寄生蜂は，アリスタライフサイ エンス (株) のサバクツヤコバチ (エルカード) のマミー カードを使用し，9月16日，9月24日は各温室に 3 カー ド（株あたり1.4頭）, 9 月30日は温室あたり 6 カード（株 あたり 2.8 頭）を，畧の中央部のトマトの葉柄にそれぞ れ設置した。

\section{4. 調査方法}

各歄から 2 株（合計 8 株）について, 上・中・下位の 各複葉各 1 枚に寄生したコナジラミ成虫数, $3 \sim 4$ 齢幼 虫数, 寄生蜂が寄生したマミ一数を調べ, 株あたりの平 均寄生数を算出した。11月 2 日に各湳 12 株（合計 48 株） について, タバココナジラミが原因で発生するトマトの 葉のすす病の発病程度を次の 4 段階に分けて数え, 発病 指数: $100 \times \Sigma$ 発病程度 $\times$ 発病株数 $/(3 \times 48)$ を算出し た。発病程度 0 : 発生なし, 1 : 一部の複葉に発生が見 られる, 2 : 複葉の半分程度に発生が見られる, 3 : 複 葉全体に発生が見られる。

屋外と各温室に温度計を設置し, 調査期間中の温度を 測定し, 午前 6 時〜午後 6 時の日中の気温を 20 分間隔で 調べ，10日ごとの平均気温を計算した。

\section{結果}

日中の平均気温は, 自然換気温室, 強制換気温室, 屋 外の順に高く, 強制換気温室の平均気温は自然換気温室 に比べ $0.2 \sim 1.6^{\circ} \mathrm{C}$ 低かった (Fig. 2)。屋外の気温の高かっ た 9 月中の強制換気温室の平均最高気温は $33.6 \sim 35.6^{\circ} \mathrm{C}$

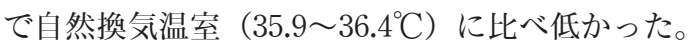

タバココナジラミの株あたり成虫数は, 強制換気温室, 自然換気温室でほぼ同じ推移を示し，9月16日以降両温 室とも漸次増加し，自然換気温室では10月28日（株あた り66.9頭) に, 強制換気温室では11月11日 (40.3頭) にピー クとなり，その後減少した（Fig. 3)。自然換気温室の成 虫数は強制換気温室に比べ10月28日，11月16日，11月25 日に有意に多かった（スチューデントの $\mathrm{t}$ 検定, $p<0.05)$ 。 


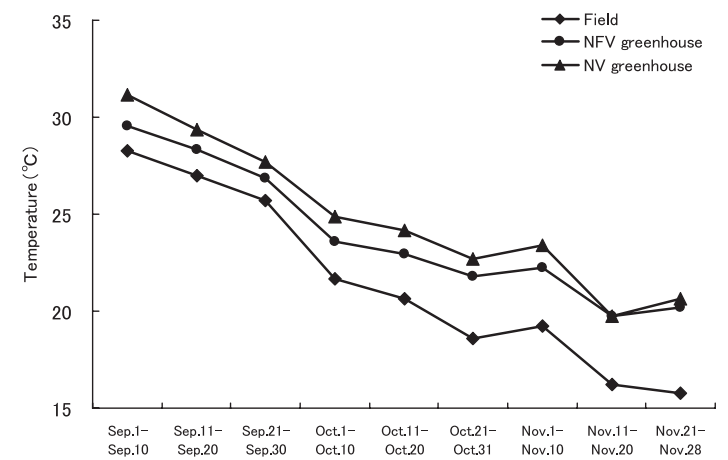

Fig. 2. Mean daytime (AM6 PM6) temperatures in the field, the greenhouse with a negative-pressure forced ventilation (NFV) system, and the greenhouse with natural ventilation (NV).

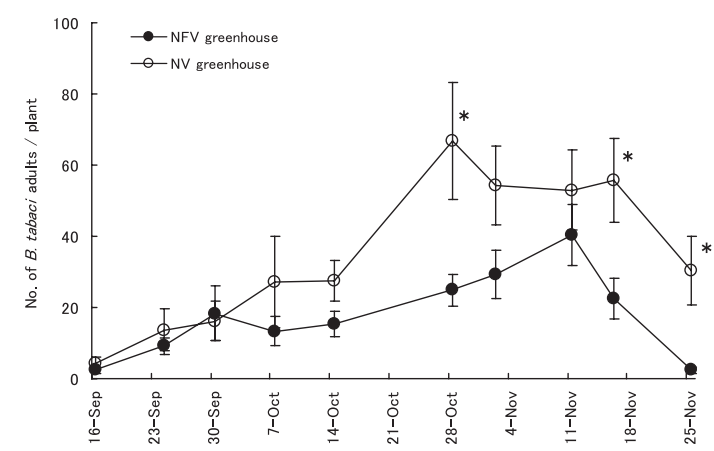

Fig. 3. Number of Bemisia tabaci adults per plant in the greenhouse with a negative-pressure forced ventilation (NFV) system and in the greenhouse with natural ventilation (NV). The bars represent standard error (SE), and the asterisks $\left(^{*}\right)$ indicate significant differences (Student's t-test, ${ }^{*} p<0.05$ ).

タバココナジラミの幼虫も成虫とほぼ同様の推移を示 し，9月23日，10月28日（自然換気温室では11月11日）, 11月25日にピークが見られ, 強制換気温室では10月28日 に株あたり 31.4 頭で最大となり，自然換気温室では11月 11日に61.3頭で最大となった。両温室のコナジラミ幼虫 数に有意な差はみられなかった（Fig. 4)。

サバクツヤコバチによる寄生は，強制換気温室，自然 換気温室のいずれも確認された。寄生数, 寄生率は, 9 月30日以降増加し, 自然換気温室の寄生数が強制換気に 比べ11月16日，11月25日に有意に多かった（Fig. 5）（ス チューデントの $\mathrm{t}$ 検定, $p<0.05$, フィッシャーの正確 確率検定, $p<0.01)$ 。

すす病の発生程度は，強制換気温室では「発生なし」 の株が最も多く発病指数は18.1で, 自然換気温室では「複 葉全体に発生がみられる」株もあり発病指数は 38.2 と強 制換気温室に比べ有意に高かった（Table 1）（ピアソン のカイ二乗検定, $p<0.05)$ 。

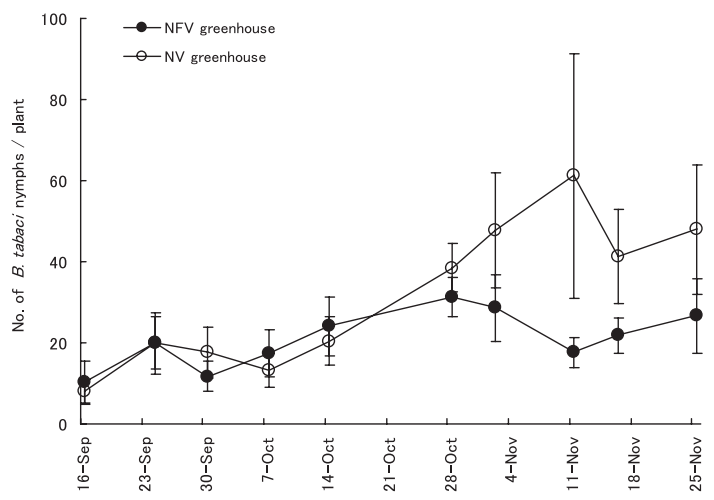

Fig. 4. Number of Bemisia tabaci nymphs per plant in the greenhouse with a negative-pressure forced ventilation (NFV) system and in the greenhouse with natural ventilation (NV). The bars represent standard error (SE), and the asterisks $\left(^{*}\right)$ indicate significant differences (Student's t-test, ${ }^{*} p<0.05$ ).

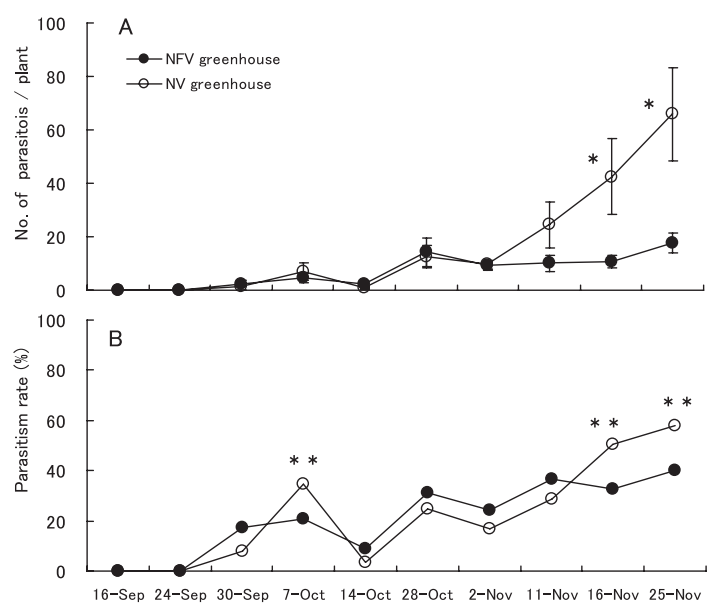

Fig. 5. (A) Number of parasitoids per plant and (B) rate of parasitism in the greenhouse with a negative-pressure forced ventilation (NFV) system and in the greenhouse with natural ventilation (NV). The bars represent standard error (SE), and the asterisk (*) indicate significant differences $\left({ }^{*}\right.$ : Student's t-test, $p<0.05$; ${ }^{*}$ Fisner's exact test, $p<0.01$ ).

\section{考察}

害虫の侵入を防ぐための防虫ネットの目合いの細密化 に起因する温室内の気温の上昇による, 作物生育への影 響や作業能率の低下などの問題 ${ }^{4,8,13,15)}$ に対しては, 自然 換気に比べ夏季に約 $2^{\circ} \mathrm{C}$ の昇温抑制効果が認められる強 制換気温室が有効とされている ${ }^{17)}$ 。実際，本試験におい ても, 強制換気温室の日中の平均気温は, 特に野外の気 温の高い 9 月でも自然換気温室に比べ $0.9 \sim 1.6^{\circ} \mathrm{C}$ 低かっ たことから (Fig. 2)，強制換気により昇温抑制が図ら れた。 
Table 1. The number of plants with various grades of black sooty disease in the greenhouse with negative-pressure forced ventilation and in the greenhouse with natural ventilation

\begin{tabular}{lccrcrcr}
\hline & \multicolumn{3}{c}{ Grade } & \multirow{2}{*}{ Total } & Occurrence index \\
\cline { 2 - 5 } & 0 & 1 & 2 & 3 & & $18.1^{*}$ \\
\hline Greenhouse with negative-pressure forced ventilation & 30 & 10 & 8 & 0 & 48 & 38.2 \\
Greenhouse with natural ventilation & 16 & 13 & 15 & 4 & 48 & \\
\hline
\end{tabular}

Grade 0: no occurrence of black sooty disease, 1: black sooty disease on less than half a leaf, 2: black sooty disease on half a leaf, 3 : black sooty disease on the whole leaf.

Occurrence index $=\{[($ number of grade 3 plants $\times 3)+($ number of grade 2 plants $\times 2)+($ number of grade 1 plants $)] \div($ total number of plants $\times 3)\} \times 100$

Asterisks $\left(^{*}\right)$ idicate signifficant difference (Chi-square test, $\left.p<0.05\right)$.

強制換気温室のサバクツヤコバチの寄生数, 寄生率は, 自然換気温室と11月 2 日，11月11日までほぼ同等に推移 したことから，この時期までは寄生蜂の探索行動，増殖 に対する強制換気の影響はなかったと考えられる。その 後の強制換気温室の寄生数, 寄生率が自然換気温室に比 べ低かった理由として，温室内の温度の低下により寄生 蜂の探索行動, コナジラミや寄生蜂の幼虫の発育が抑制 されたためと考えられる。この温度の低下は，10月以降 換気による屋外の冷たい空気の大量の取り込みによる一 時的な温度の低下によると思われる。

強制換気温室のタバココナジラミの成虫と幼虫の発生 は，10月14日または10月28日まで自然換気温室と同程度 であったことから，この時期まではタバココナジラミの 増殖に対する強制換気の影響はなかったと考えられる。 その後の強制換気温室のタバココナジラミの発生が自然 換気温室に比べ少なかった理由として，10月以降温室内 の気温の低下により，タバココナジラミの発育が抑制さ れたためと考えられる。

強制換気温室では，換気中の站間の風速は $1 \mathrm{~m} / \mathrm{s}$ 程度 で，タバココナジラミ，サバクツヤコバチの献間の移動 に対して風の影響はあったと思われる。しかし，㰴の中 はほぼ無風で，株の周辺ではタバココナジラミ，サバク ツヤコバチの飛翔が観察されたことから，これらに対す る風の大きな影響はなかったと思われる。

タバココナジラミの密度は，すす病がいずれの温室で も確認されたことから十分に抑制されなかった。これま でのタバココナジラミに対するサバクツヤコバチのほ場 試験では，サバクツヤコバチをポインセチア温室に毎週 株あたり 3 頭を18週放飼 ${ }^{21)} ， 2.9$ 頭と3.7頭の放飼 ${ }^{6)}$ ，また は 1 頭を 14 週間以上の放飼 ${ }^{5)}$ した結果，いずれも防除効 果が認められた。これらの成功事例に比べると，本試験 ではタバココナジラミの密度に対して，寄生蜂の放飼回 数と株あたり放飼量（1.4頭を 2 回と 2.8 頭を 1 回）がと
もに少なかったため十分にコナジラミを抑制できなかっ たと考えられる。

本試験では, 試験期間中農薬の散布は行わなかったが, タバココナジラミの密度を下げるためには, 天敵と農薬 を組み合わせる必要があると思われる。例えば，サバク ツヤコバチを毎週株あたり 1 頭の放飼に加え IGR 剂（ア プロード）を 2 回散布した温室では高い防除効果がみら れた ${ }^{21)}$ 。今後, 強制換気温室でもコナジラミの発生密度 が低い時の寄生蜂の防除効果や寄生蜂と農薬を組み合わ せた防除効果の検証が必要である。

また，強制換気温室のすす病の発生が自然換気温室に 比べ少なかった理由として，10月以降温度の低下により コナジラミの吸汁活動や菌の発育の抑制, 風により菌の 付着が妨げられたことなどが考えられる。

これらの結果から，天敵寄生蜂の探索行動，増殖に対 する強制換気の影響はなく，強制換気温室においても天 敵寄生蜂はコナジラミの防除に有効である。季節によっ ては強制換気による温室内の気温低下によって天敵寄生 蜂の活動が弱まる可能性があるが，それ以上にタバココ ナジラミに対しては強い影響があると考えられ，実用上 の問題はないと思われる。タバココナジラミよりも低温 に強いオンシツコナジラミに対する影響は，さらに検討 が必要である。強制換気下での病害虫防除に関する研究 事例は少なく, 今後の詳細な調査や，施設トマトではコ ナジラミ類以外にハモグリバエ類，アザミウマ類などの 害虫も発生するため, これら害虫を含めた防除体系の検 証が必要である。

\section{摘 要}

風速 $1 \mathrm{~m} / \mathrm{s}$ 程度の陰圧式強制換気システムに防虫ネッ 卜を組み合わせた強制換気温室と自然換気温室におい て, タバココナジラミに対するサバクツヤコバチの防除 効果を比較し, 強制換気温室における天敵寄生蜂の利用 
技術の有效性の評価を行った。強制換気温室の日中の平 均気温は，9月でも自然換気温室に比べ $0.9 \sim 1.6^{\circ} \mathrm{C}$ 低く 昇温抑制が図られた。強制換気温室のサバクツヤコバチ の寄生数, 寄生率は, 自然換気温室と11月上・中旬まで ほぼ同等に推移した。また，強制換気温室のタバココナ ジラミの成虫と幼虫の発生は，10月中・下旬まで自然換 気温室と同程度であった。これらの結果から，天敵寄生 蜂の探索行動, 增殖に対する強制換気の影響は小さく, 強制換気温室においても天敵寄生蜂はコナジラミの防除 に有効であると考えられた。

\section{引用文献}

1）青木克典・下烟次夫・野村康弘（1992）関西病虫研報 34 : 55.

2) Gerling, D., Ò. Alomar and J. Arnò (2001) Crop Protection 20: 779-799.

3）原田正剛・中野昭雄（1999）徳島農試研報 35 : 34-43.

4）久富時男・藤本幸平（1977）施設果菜の温度管理。施設園 芸の環境と栽培 (位田藤久太郎編著)。誠文堂新光社, 東京, pp. 85-108.

5) Hoddle, M. S., R. G. Van Driesche, J. P. Sanderson and O. P. J. M. Minkenberg (1998) Bull. Entomol. Res. 88: 47-58.

6) Hoddle, M. S. and R. G. Van Driesche (1999) J. Econ. Entomol. 92: 811-824.
7）飯田博之・北村登史雄・本多健一郎・水澤靖弥・鎌田 茂 ・大野 徹・広瀬拓也 (2009) 関西病虫研報 $51: 75-77$.

8）上遠野冨土夫・河名利幸（1996）植物防疫 50：468-471.

9）鹿島哲郎・野原 努・加藤史歩・冨田恭範 (2008) 関東病 虫研報 $55: 113-118$.

10) Kato., K., M. Onuki, S. Fuji and K. Hanada (1998) Ann. Phytopathol. Soc. Jpn. 64: 552-559.

11）勝山直樹 - 福田富幸 - 越川兼行 - 田口義広（2005）岐阜農 技研報 $5: 13-19$.

12）小林政信（2007）植物防疫 $61: 21-26$

13）松浦 明 - 田村真理子・志摩五月 (2005) 九病虫研会報 51 : 64-68.

14) Matsuura, S. and S. Hoshino (2009) Appl. Entomol. Zool. 44: 143-148.

15）小川恭弘・内川敬介（2004）九病虫研報 50:72-76.

16）大井田寛・津金胤昭 - 久保周子・草川知行 - 清水喜一 野々宮弘明・風戸治子・中臺敬子（2007）関東病虫研報 $54: 143-150$.

17）大石直記・守谷栄樹（2004）農耕と園芸 $8: 51-54$.

18) Sugiyama, K., K. Matsuno, M. Doi, A. Tatara, M. Kato and Y. Tagami (2008) Appl. Entomol. Zool. 43: 593-598.

19）杖田浩二・田口義広（2006）関西病虫研報 $48: 23-28$.

20) Yano, E. (2004) J. Asia-Pacific Entomol. 7: 5-11.

21) Van Driesche, R. G., M. S. Hoddle, S. Lyon and J. P. Sanderson (2001) Biol. Control 20: 132-146. 